\title{
The Role of Mamak as Adult Educator in Family Strengthening in Modernization Era:
}

\author{
Minangkabau Family in Indonesia
}

\author{
Ridha Husnul Hayati ${ }^{1, *}$, Sitti Chotidjah ${ }^{2}$, Yanti Shantini ${ }^{1}$ \\ ${ }^{1}$ Department of Community Education, ${ }^{2}$ Department of Psychology \\ ${ }^{1,2}$ Universitas Pendidikan Indonesia \\ Bandung, Indonesia \\ *ridhahusnulhayati@upi.edu
}

\begin{abstract}
Education in Minangkabau matrilineal family is based on the responsibility of the Mamak (Uncle) to the nephew, who cooperated with the mother and other relatives. In Minangkabau society, Mamak has a big role and responsibility to their nephews. Mamak is a protector and should foster a nephew so that in the future he can replace him as the person in charge and the successor of the family's survival. However, in the modern era, there has been a shift in the role of the Mamak which has been taken over by the nuclear family. The purpose of this study is to describe the role of Mamak as an educator in strengthening the nuclear family in the modernized era. This research includes a quantitative approach with descriptive analysis. In this study, the analysis of $\mathbf{4 0}$ people was done by purposive sampling technique. The data was collected in the form questionnaire and processed with a percentage formula. Based on the results obtained from data analysis, it is concluded that the role of educators in strengthening the nuclear family in the modernization era, the role of Mamak is in the enough category with a proportion of $50 \%$.
\end{abstract}

Keywords-educator, nuclear family, matrilineal, Minangkabau, modernization era

\section{INTRODUCTION}

The Minangkabau ethnic community is a society adhering to the matrilineal kinship system. Matrilineal is a lineage system where the mother determines the lineage. This means that nurture and inheritance are passed down through the maternal lineage. Each individual will see himself as a mother's descendant regardless of his father's offspring. The matrilineal kinship system in Minangkabau, one rumah gadang is inhabited by a family whose blood is according to the maternal lineage. So that in Minangkabau culture, the family does not only consist of father, mother, and child but extends into one large family that is traced along matrilineal lines [1].

Related to the Minangkabau people who embrace the matrilineal kinship system, the role of fostering is not only the responsibility of the father and mother but also extends to the mother's siblings such as mamak. According to Minangkabau customs, mamak in general is the brother of his mother, brother, or sister [2]. Apart from that, the Minangkabau also knows mamak specifically who heads the tribe which is commonly called niniak mamak. Each community is grouped into their respective tribes and each tribe is led by a niniak mamak or who we know as a headman. However, what is meant here is mamak in the family environment (mamak tungganai) which plays an important role in guiding its nephew [3].

In the Minangkabau community, a mother has an important role in parenting. Mothers also play a central role in education; security; wealth; and family welfare. However, in the Minang ethnic community, mothers also give up childcare to the mamak [4]. Therefore, in the Minangkabau family structure, the organizational line is "mamak and nephew", while the biological pathway is "mother and child".

This results in differences in parenting roles between fathers in general and fathers' roles in Minangkabau [5]. In general, the father plays a role in authority because the father is a leader in a family. Shofiah and Yulianti [6] states that fathers are responsible for three main tasks. First, fathers must teach their children about God and educate their children in religious teachings. Second, a father must take a leadership role in his family. Third, the father must be responsible for discipline. Thus he became an authority figure. Meanwhile, in Minangkabau custom, the role of the father is normatively left to the mamak.

In the Minangkabau kinship system, the father is a sumando, his power is weak unlike in the nuclear family. The father's responsibility is to earn a living, cultivate his wife's inheritance [4]. As for the children's affairs, the mother is entrusted to her uncle or mother. So in other words, the role of the father in parenting is taken by the mamak [2].

Related to the role of the mamak, the Minangkabau custom gives a position and at the same time a heavier obligation to the mamak than the obligation of the mother. Adat requires that mamak have a role in educating and guiding their nephew [2]. Mamak also has a special role in economic, educational, 
religious, traditional, wedding ceremonies, and traditional Minangkabau life [2]. The mamak is obliged to the niece of the woman to guide and prepare her to receive the inheritance and as the successor of the descendants. Especially for male nephews, Mamak is obliged to guide him to be able to maintain the inheritance and prepare him to inherit the function of the Mamak as a leader in the community and tribal environment [7].

Mamak acts as a guide for his nephew, meaning as a mamak, he must have exemplary characteristics so that his nieces and nephews imitate his character. Mamak is obliged to guide nephews in the field of custom and provide supervision of their nephews such as the education, safety, and welfare of the nephew.

Lkam [8] the responsibility of mamak includes resolving disputes that occur between a group, in the development of inheritance, marriage, and all matters relating to the welfare of the nephew are the responsibility of the mamak including household economic problems.

The relationship between mamak and kemanakan is contained in the duties and responsibilities of a mamak. In this case, it functions as a mentor and mentor of the closest maternal family members [9]. In the Minangkabau community, mamak traditionally play an important role in the extended family, including visiting the kemanakan house at every opportunity and on certain days, paying attention to all the children in terms of their daily behaviour, mamak pointing, teaching kemanakan and providing knowledge about adat and skills for male children according to their abilities. Besides that, the mamak also has the responsibility to find a marriage mate even if he is able to build a house for the children [10].

Navis [2] divides the level of Mamak, namely; Mamak tungganai, namely Mamak as a leader in the family environment who plays an important role in guiding their descendants. Furthermore, the Mamak clan, namely the chief who leads the clan. Finally, the tribal Mamak is the chiefs who are made the leaders of their people. In this study, Mamak is meant as Mamak tungganai, where Mamak is a leader in the family environment who plays an important role in guiding his nephew.

Thus the authors conclude that the role of the mamak, in general, is guiding nephew, taking care of nephew marriages, maintaining inheritance, dispute resolution, niece's household economy and all matters relating to nephew welfare. In a society, the mamak is a king, his good qualities must be obeyed and imitated.

Seeing the times and the consequences of modernization, symptoms of changes in kinship relations have emerged. Nowadays the role of the mamak in Minangkabau customs has evolved very changed. The fact that it is now found that the role of a mamak has begun to shift in the sense that the responsibility remains but in other forms, for example in matters of traditional ceremonies, inheritance, tribal matters and so on. Meanwhile, in matters of economy, education, and the religious sector which had been his responsibility so far, the mamak was no longer fully ruled.

In terms of education, the mamak is responsible for the education of his nephew. Mamak taught about how to get along well, about religion, about skills or household education and the formal education of his nephew [3]. Meanwhile, in terms of economy, the mamak must take part in paying attention to and helping the children of their nephew for the continuation of their daily lives amid society. Niniak mamak always controls and receives good or bad information about the life of his nephew, that way mamak can find out the condition of his nephew [11]. Mamak also plays a role in religious matters, in which niniak mamak is responsible for carrying out the religious education of their nephew. In the field of adat, the role of the mamak is to provide good directions and instructions to the nephew if any of the children of his nephew violates the adat from an aspect; economic, social, cultural and so on. This is what makes niniak mamak so tall and dignified in the eyes of his nephew [12].

Talking about mamak as nephew educators, learning in the family uses a variety of approaches, including a continuum approach from pedagogy to andragogy. Pedagogy is the art and science to teach children, while andragogy is the art and science to help adults do learning activities [13]. The process shifts gradually and naturally according to the development of age and position, based on the family culture it belongs to.

Educational efforts in the Minangkabau matrilineal family use a continuous approach, from pedagogy to andragogy. Ethno-pedagogy seeks to inherit matrilineal culture in nephew (learners) who will reach adulthood. Andragogically, the family sees the development of age and maturity of nephew children, in inheriting or continuing the position and position of their mamak (especially boys) in relatives and society.

In this case, researchers researched how the role of mamak as adult educators (nephew) in strengthening the nuclear family in the modernization era in the Minangkabau family. The purpose of this study is to describe the role of mamak as educators in strengthening the nuclear family in the modernization era.

\section{LITERATURE REVIEW}

\section{A. Kinship System in Minangkabau}

The Minangkabau kinship system adheres to a matrilineal system. The matrilineal system which is used to draw the lineage according to the maternal lineage makes women in a Minangkabau society increasingly occupy a special place. Matrilineal comes from two words, namely matri and lineal. Matri means mother and lineal means line, so matrilineal lineage is based on the mother's side. Muqtafi [14] said that the characteristic of the matrilineal system in Minangkabau is that the descendants are counted from the mother's descendants. The child lives and is raised in the mother's house, while the husband is someone else in the offspring. 
Each family is the smallest genealogical unit called samande (biological), which is headed by a mother's brother called a mamak who lives in a rumah gadang and is headed by the oldest mamak called tungganai. Life in this rumah gadang is called saparuik (biological) which consists of the family tree. Saparuik is the most important functional unit. A collection of several lungs that come from the same grandmother is also called the clan. The people headed by the oldest tungganai called the pengulu. Then, from some people who have children, it is also called sasuku or sakampung, headed by the head of andiko.

A mamak in a saparuik functional unit does not only function as the person in charge of family welfare, but is also responsible for the education and personality development of his nephew. Mamak is definitively called the mother's brother, while sociologically all males of the older generation are called mamak.

The group of a community that has the leadership is headed by a mamak. Because they function as leaders, mamak is seen as kings. In the matrilineal system the members of the clan consist of, mother, child and mamak. The position of the father remains as a family member of the clan where he belongs, which is another family of his wife and children. A mamak has an important role in people. Mamak is the one who determines everything in the tribe. Mamak is the brother of the mother's side. If the mamak is the leader in the clan, then he is called the penghulu. Penghulu is a title given from generation to generation through the maternal line, from mamak to nephew. The customary mamangan says "Kemenakan barajo kamamak, mamak barajo kapangulu, pangulu barajo kananbana, bana berdiri sendirinyo" (kemenakan baraja ke mamak, mamak baraja ke penghulu, penghulu baraja kekebenaran, kebenaran berdiri sendirinya" [14].

Minangkabau socio-cultural conditions, place women in the highest position. Minangkabau women are independent people. Minangkabau women have a supervisory basis, a moral basis, and protect not only their families but also their families. According to Islamic cultural observers [15]. "Minang women in a central position, become owners of all wealth, houses, children, ethnic groups and even the common people", placing men in roles. Protectors, custodians and custodians of the assets of their women and their children. In this cycle, the Minangkabau Generation is born with mother (female) ethnicity, with the title mamak (matrilineal line), showing its egalitarianism, a beautiful cultural compound.

The position of women in the Minangkabau family is named semarak kampuang or the hiasan Nagari. It means a traditional house that cannot be left by women. After the marriage, the house and family land are guarded and held by women, called Harta Perempuan. The unique position of women is not only at the family level in Minangkabau. In a clan meeting, women's opinion means a lot and inheritance cannot be pawned without the help of women. If the people want to pawn a mortgage, then women who are still girls from the heirs will be asked to appear, with the intention that there are witnesses who are of course still long and who are relied upon and even active in defending the rights they have or hold over the land. So, it can be seen that women advancing as pambela pusako.

A mother in Minangkabau has a very important position in determining something. The customary fatwa says that the mother (woman) is the Limpapeh Rumah nan Gadang, where the position of a mother is very influential in her relatives. Limpapeh is a kind of butterfly that is very beautiful. Limpapeh is then likened to tunggak tuo of a rumah gadang, which also has power over property, such as; fields, forests, land, and others. All of this is in the hands of the mothers who are symbolized as amban puruak. Amban puruak is defined as a key handle. This means that a woman is believed to be the safe keeper and custodian of family wealth in the form of assets [14].

The Minangkabau people know the term mutual tribal mother, if they are still alive they are termed bundo kanduang. Regarding family matters, the tribal mother remains the highest authority in people. Likewise, regarding the marriage of teenage boys, the most important opinion is the tribal mother who is still alive and after her, as well as other women in the clan.

\section{B. Mamak and Nephew in Minangkabau}

1) Definition of Mamak: The meaning of mamak in the Big Indonesian Dictionary is a mother. In some cultures, the call for mamak is also defined as the call for mother, such as the Batak culture [16]. Different from the understanding of mamak in the Minangkabau ethnicity, literally mamak is the mother's brothers. Sociologically all males of the older generation are mamak [2]. Child kinship between mamak and nephew is the relationship between a boy and his mother's brother, or the relationship between a boy and his sister's children [2]. To a person, his mother's brother is her mother and she is her mother's brother. Meanwhile, his sister's child is a nephew and he is a mother for his sister's children.

2) Nephew in Minangkabau: Nephew is a son or daughter of a sister [10]. If the mamak has responsibility for the nephew, then the nephew also have the responsibility for the mamak. Like visiting the mamak's house every time there is a chance, especially on Islamic celebrate. If the nephew want to migrate, he asks the mamak for advice first and when he returns from the overseas, he will visit the mamak. If the mamak is sick at the child's house, then in deliberation, the mamak will take to the rumah gadang. Likewise, if a mamak dies at her child's house, the nephew will collectively ask the children to be buried in the family heirloom, the child who is sincere or not sincere must give up [10].

\section{METHODS}

In this study, the approach used is a quantitative approach because the data collected in this study is in the form of numbers (numbers) to symbolize all events or events analysed 
by means of statistical techniques. According to Izaak Latanussa [17]. "Quantitative research is research that applies the number method which aims to describe an observation or object of observation where the number will be part of the measurement process.

This research uses descriptive analysis method. According to Sugiyono [18], descriptive analysis is a statistical analysis used to analyse data by describing the data that has been collected. The criteria for respondents' answers can be used in the following categories:

- If the TCR is between $76-100 \%=$ Good

- If the TCR is between 56-75.99\% = Enough

- If the TCR is between $0-55.99 \%=$ Less

Sampling of this research data using purposive sampling technique, namely the technique of determining the sample by considering certain aspects. The selection of a group of research subjects in purposive sampling, based on certain criteria which are considered to have a close relationship with the population criteria. Therefore, in other words, the sample units contacted were matched with predetermined criteria according to the research problem or research objective.

This research was conducted in Singguling Village, Lubuk Alung District, Padang Pariaman Regency, West Sumatra Province. As for the population in this study amounted to 596 people, namely with the criteria of nephews who are adults aged 15-24 year. The sample in this study were 40 people who were obtained using purposive sampling technique. The characteristics of the respondents who were sampled were nephews who were adults but not married with the age group of 15-24 years who came from Singguling Village, Lubuk Alung District and had a biological mamak.

In this study, data collection tools used a questionnaire with a total of 62 items. The questionnaire is a data collection tool created by providing a set of written statements or questions to be answered by research respondents [18]. This technique is used to obtain empirical data by distributing research questionnaires to respondents. Respondents who provide in the questionnaire from qualitative data are converted into quantitative data by measuring it using a Likert scale form. The changed data will be adjusted according to the nature of the statement in which the answer Very Fit (SS) is given a score of 4 , In accordance (S) is given a score of 3, the answer is not suitable (TS) has a score of 2, while the answer is Very Unsuitable (STS) is given a score of 1 which is a positive statement. It's different if the statement is negative then the answer is Very Fit (SS) the score is 1, Fit (S) is given a score of 2, Not Suitable (TS) is given a score of 3, and Very Unsuitable (STS) is given a score of 4 .

To test the research instruments in this study, it is necessary to test the reliability and validity. The purpose of the validity test is a test tool for the instrument used whether it is valid (valid) to be used in measuring variables or not. While the reliability test aims to determine whether an instrument can be answered consistently or not.

\section{FINDING AND DISCUSSION}

Based on the research that has been done, the results are presented as in the following table:

TABLE I. PERCENTAGE OF MAMAK Roles

\begin{tabular}{|l|l|l|l|}
\hline \multicolumn{1}{|c|}{ Classification } & \multicolumn{1}{c|}{ Category } & \multicolumn{1}{c|}{ F } & \multicolumn{1}{c|}{$\%$} \\
\hline$<90$ & Good & 9 & 22,5 \\
\hline $90-135$ & Enough & 20 & 50 \\
\hline$<135$ & Less & 11 & 27,5 \\
\hline
\end{tabular}

The role of mamak towards nephew

For more details, it can be seen in the following graph:

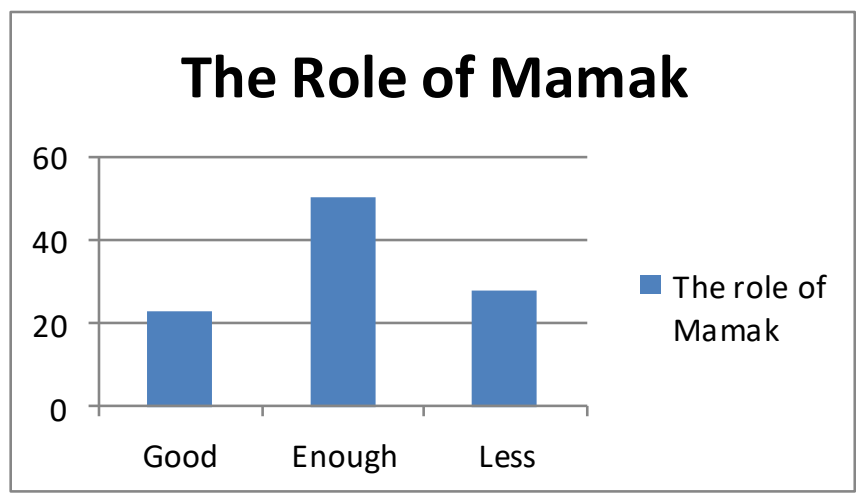

Fig. 1. The role of mamak

Based on the results of the item analysis carried out on the nephew of the mamak's function as educators in the Minangkabau family, it was found that the role of the mamak towards the nephew of the Minangkabau family in the modernization era was still quite important. It can be seen from the 40 research sample, it was found that respondents who felt that the mamak had a role as educators in strengthening the nuclear family were as many as 9 respondents $(22.5 \%)$, and respondents who felt that the mamak had a sufficient role as educators in strengthening the nuclear family were as many as 20 respondents $(50.0 \%)$, while nephew who felt that mamak did not play a role as educators in strengthening the nuclear family was 11 respondents $(27.5 \%)$. So the results of the research as a whole the role of the mamak as nephew educators in the Minangkabau family in the modernization era are in the quite role category.

In theory Samin [19] that the role of mamak towards nephew in the Minangkabau family has a very important role. Mamak plays a role in taking care of her nephew, which means how niniak mamak can look after, nurture, and educate nephew to become good individuals. In essence, the nephew are under the auspices of the niniak mamak who are directed according to the prevailing customs. 
Based on the findings and the theory, there is a change in the role of the mamak in educating nephew in the Minangkabau family due to several factors, such as the mamak who has been migrating for a long time, so that the nephew does not feel the role of the mamak in everyday life. In addition, the effect of strengthening the nuclear family also resulted in the weakening of the role of the mamak in the Minangkabau family. Strengthening the nuclear family here means that all forms of childcare have been taken over by their respective parents without the intervention of the mamak.

In accordance with previous research Handayani [20], the results showed that the shift in the role of niniak mamak before the modernization era, namely in caring for nephew, in marriage, in dispute issues, and maintaining inheritance. And the shift in the role of niniak mamak that occurred during the modernization era, namely caring for nephew in daily life, in marriage in terms of finding a mate, and maintaining inheritance. In addition, there are also, factors that influence the role of niniak mamak, which consists of the strengthening of the role of the nuclear family, the existence of a culture of migration, the economy, and education.

The results of the analysis for the respondent's achievement level (TCR) on each indicator can be illustrated that in the economic sector, mamak plays a sufficient role in providing assistance when nephew experience financial difficulties and also in providing pocket money to nephew. In the field of education, the role of the mamak is very large in providing a good example and also instilling the value of honesty in nephew. However, Mamak does not play a role in supervising formal education. In the religious field, mamak plays a role in reminding their nephew to perform worship such as praying and fasting, mamak will admonish them if they do not perform worship and remind them to read the Quran. However, mamak is not responsible for the implementation of religious education for nephew in Surau. From the presentation of the results of this study, it can be concluded that mamak does not play a role in economic matters but is sufficient in terms of education and religion.

Based on the theory Samin [19], in economic matters, the mamak plays an important role in paying attention to and helping nephew for the continuation of their daily lives in the midst of society. In the matter of education, mamak is responsible for the education of her nephew, such as how to get along well, skills and household education, and is responsible for the formal education of her nephew. Meanwhile, in the matter of religion, the role of the mamak towards the nephew is very large, because the mamak is also responsible for the implementation of the religious education of his nephew.

According to previous research Handayani [20] states that the role of mamak in Minangkabau culture has begun to diminish towards her nephew. When viewed from an economic problem, this is due to the economic limitations experienced by the mamak, so that it affects how he carries out his function as a mamak who should help his nephew. Apart from that, education is also one of the factors that cause social change in society, including the relationship between a niniak mamak and her niece. Moreover, what we know, public education has been growing from time to time. Niniak mamak must be able to balance the education of nephew's children so that what they convey can be well received by nephew.

In addition, the results of research conducted Hafizah [21] state that the role of mamak in the economic sector is no longer being felt. This is because mamak prioritizes children and wives, besides that mamak rarely manage family heirlooms, the results of which are used to finance their nephew. Because the result of the mamak's personal search is to support his child, while for his nephew it is financed by the management of inheritance such as rice fields and fields. By not taking part in managing the inheritance, the economic life of the nephew does not become a burden for the mamak, it is different if the mamak is able and voluntarily wants to help the economic life of the nephew. In terms of education, mamak used to function in terms of educating nephew in terms of ethics, how to eat, or giving money to school. But now the problem of education is given entirely to parents and teachers in schools. So that if a nephew makes a mistake it is not the name of the mother that is bad anymore but the name of the child's parents. Whereas in the religious field, mamak also plays an important role in the implementation of nephew religion, mamak as protectors and role models for nephew, mamak must be able to control how the nephew are religious. However, currently because of the busyness of the mamak, it is the parents and teachers of the Quran that teach children in the field of religion.

\section{CONCLUSION}

Based on the results of research on the role of the mamak as nephew educators in the Minangkabau family, it can be concluded that the mamak is quite a role with a percentage of $50 \%$. This means that half of the respondents stated that mamak had a role to play with nephew. Each indicator can be concluded that Mamak has no role for nephew in the economic sector, Mamak has a significant role towards nephew in education and Mamak has a significant role towards nephew in the field of religion

\section{ACKNOWLEDGMENT}

Thanks to respondents in Lubuk Alung Village, Lubuk Alung District, Padang Pariaman Regency, West Sumatra Province, and all parties who have provided a lot of assistance and contributed so that research can be carried out well.

\section{REFERENCES}

[1] K. Koentjaraningrat, "Manusia dan Kebudayaan di Indonesia," Djambatan, 2010.

[2] A.A. Navis, Alam terkembang jadi guru: Adat dan kebudayaan Minangkabau: Grafiti Pers, 1984.

[3] M. Anjela, "Pergeseran Peran Mamak Terhadap Kemenakan Dalam Adat Minangkabau di Kanagarian Simalanggan,” Jom FISIP, vol. 1, no. 9 , pp. 1-15, 2014. 
[4] S. Natin, "Perubahan sosial kedudukan dan peran mamak terhadap anak dan kemenakan di ranah minang," Mimbar Hukum-Fakultas Hukum Universitas Gadjah Mada, vol. 20, no. 2, pp. 333-350, 2008.

[5] C.W. Watson and T. Kato, Matriliny and Migration: Evolving Minangkabau Traditions in Indonesia, 1983.

[6] H. Harmaini, V. Shofiah and A. Yulianti, "Peran ayah dalam mendidik anak," Jurnal psikologi, vol. 10, no. 2, pp. 80-85, 2015.

[7] S. Widihastuti, P.W. Kuncorowati and I. Nurhayati, "Pudarnya peran mamak minangkabau perantauan di Kota Yogyakarta terhadap kemenakan,” Jurnal Civics: Media Kajian Kewarganegaraan, vol. 16, no. 2, pp. 187-198, 2019.

[8] LKAM, Pengetahuan Adat Minangkabau. Padang: Ratu Grafika Padang, 2000.

[9] A. Syarifoedin, Minangkabau dari dinasti Iskandar Zulkarnain sampai Tuanku Imam Bonjol. Jakarta: PT Gria Media Prima, 2011.

[10] F.M. Arif, Hubungan Mamak dan Kemenakan dalam Sistem Kekerabatan Minangkabau. Lampung: Fakultas Keguruan dan Ilmu Pendidikan Universitas Lampung, 2016.

[11] M. Zainuddin, Minangkabau dan Adatnya. Yogyakarta: Ombak, 2013.

[12] N. Nazaruddin, Kelahiran dan Pengasuhan Anak di Minangkabau. Padang: Universitas Andalas, 1982.

[13] D. Sudjana, Pendidikan Nonformal. In Ilmu \& Aplikasi Pendidikan. Bandung: Alfabeta, 2007.
[14] M. Muqtafi, "Budaya Masyarakat Minangkabau Dalam Novel Memang Jodoh Karya Marah Rusli,” Biomass Chem Eng, vol. 49, pp. 23-26, 2015.

[15] M. Abidin, Membangun Karakter Masyarakat Minangkabau di Sumatera Barat Berasaskan ABS SBK. Di Surau Buya Masoed Abidin, 2010.

[16] R.N. Aninda, "Nilai Anak Perempuan pada Keluarga Batak Ditinjau Dari Ibu Dewasa Awal dan Dewasa Madya,” Calyptra: Jurnal Ilmiah Mahasiswa Universitas Surabaya, 2013.

[17] N.I. Sudjana, Penelitian dan Penilaian Pendidikan. Sinar Baru Algensindo, 2004

[18] S. Sugiyono, Metode Penelitian Kuantitatif Kuantitatif dan RND, 2010.

[19] Y. Samin, Peranan mamak terhadap kemenakan dalam kebudayaan Minangkabau masa kini. Bagian Proyek Pengkajian dan Pembinaan Nilai-Nilai Budaya Sumatera Barat, 1996.

[20] M. Handayani and V.I.S. Pinasti, "Pergeseran Peran Ninik Mamak Pada Masyarakat Minangkabau Dalam Era Modernisasi (Studi kasus di Nagari Kamang Hilia, Kecamatan Kamang Magek, Agam, Sumatera Barat)," E-Societas, vol. 7, no. 7, 2018.

[21] H. Hafizah, "Pergeseran Fungsi Mamak Kandung Dalam Pelaksanaan Adat Minangkabau Pada Masyarakat Jorong Batu Badinding Nagari Limo Koto Kecamatan Bonjol Kabupaten Pasaman," Jurnal Ilmu Budaya, vol. 16, no. 1, pp. 29-48, 2019. 